DOI: 10.46340/eujem.2020.6.3.7

Lesia Hazuda, ScD in Economics

ORCID ID: http://orcid.org/0000-0003-2469-3748

Uzhgorod National University, Ukraine

Viktoriia Hertseh

ORCID ID: http://orcid.org/000-0003-4613-2829

Uzhgorod National University, Ukraine

\title{
SOCIO-INFRASTRUCTURE SUPPORT OF RURAL AREAS
}

\author{
Леся Газуда, д.е.н. \\ Вікторія Герцег \\ ДВНЗ "Ужгородський національний університет"

\section{СОЦІОІНФРАСТРУКТУРНЕ ЗАБЕЗПЕЧЕННЯ СІЛЬСЬКИХ ТЕРИТОРІЙ}

The current state of Ukraine's economy and the desire to integrate into the European Community requires significant changes in the field of governance at all levels, requires the development of measures and mechanisms for sustainable development of the Ukrainian countryside. Socioinfrastructure support of rural areas is a necessary prerequisite for the existence and reproduction of human potential in rural areas.

It is worth noting that social infrastructure is a rather complex object of research and management, so there is a need to assess its condition to overcome the negative trends that hinder its development.

The article considers the main components of socio-infrastructure support of rural areas, analyzes their condition, outlines the main problems and areas for improvement. It is necessary to monitor the process of the formation and implementation of state strategies for rural development.

Keywords: socio-infrastructure support, rural areas, development, tendencies, population.

Мета статті - дослідження стану соціоінфраструктурного забезпечення сільських територій та обгрунтування можливих перспективних напрямів розбудови українського села.

Аналіз останніх досліджень і публікацій. Проблеми розвитку соціоінфраструктури сільських територій розглянуто у наукових працях вчених-економістів, зокрема В. Андрійчука, О. Бородіної, П. Гайдуцького, І. Гончаренка, М. Кропивки, О. Павлова, П. Саблука, В. Юрчишина та інших. Більшість досліджень стосуються як окремих елементів інфраструктури сільських територій, так і загальних питань забезпечення сільського розвитку.

Постановка проблеми. Соціальна інфраструктура відіграє важливу роль у соціальноекономічному зростанні як регіону, так і держави в цілому. Вона $є$ одним із вагомих чинників забезпечення якості та кращого рівня життя сільських жителів, задоволенні їх матеріальних i духовних потреб, розбудови та розвитку сільської місцевості.

Сучасний стан соціоінфраструктурного забезпечення сільських територій $\epsilon$ близьким до критичного й занепадає, тому потребує інституційної та матеріальної підтримки з боку держави. Державна політика розвитку села повинна базуватися на поєднанні зусиль органів державної влади та органів місцевого самоврядування у розв'язанні соціальних проблем розвитку сільських територій.

Через неналежне соціоінфраструктурне забезпечення значна частина сільських мешканців змушена покидати власні домівки та від'їжджати у міста чи взагалі закордон у пошуках кращого життя, що призводить до відпливу працездатного населення із сільських територій та деградації села.

Реалізація багатофункціональної ролі соціоекосистеми, що включає сільське господарство, сільську місцевість і сільську спільноту, спрямовує на розв'язання проблем і завдань розвитку села на засадах пріоритетності і збалансованості економічної, соціальної та екологічної складових ${ }^{1}$

${ }^{1}$ Газуда, Л. М., Ерфан, В .Й., Газуда, С. М. (2015). Сільський розвиток регіону. Ужгород: Сабов А. М., 10. 
Сільська територія - це не тільки просторовий базис виробництва, а й природне середовище та місце життєдіяльності людей. Саме тому від людини, іiі культурно-освітнього рівня, професійної підготовки, навичок, вмотивованості, бажання і вміння працювати визначається ефективність використання території. ${ }^{1}$

Забезпечення збалансованого розвитку сільських територій не варто розглядати лише з точки зору підтримки аграрної сфери, це - покращення умов життя, праці, побуту, дозвілля сільських мешканців, забезпечення високої якості людського потенціалу, вирішення питань оздоровлення та демографічної ситуації.

В умовах активізації євроінтеграційних процесів сучасне українське село потребує ефективних зрушень та реформувань, зосереджених на покращення умов та рівня життя мешканців сільських територій, вирішення проблем соціальної та виробничої інфраструктури.

Дослідження В. Рябоконя базується на виокремленні галузевого та територіального підходів до забезпечення розвитку сільських територій. ${ }^{2}$

Галузевий підхід спрямований на розвиток аграрної сфери та агробізнесу в сільській місцевості. При цьому, основні напрями підтримки стосуються забезпечення конкурентоспроможності сільськогосподарського виробництва, підвищення доходів суб'єктів аграрного господарювання, розв'язання проблем зайнятості, зокрема створенню нових робочих місць у сільській місцевості.

Територіальний підхід зумовлюється інтегрованим підходом, оскільки передбачає комплексний розвиток сільських територій з урахуванням їх природно-кліматичного, демографічного, соціально-економічного потенціалу. До основних напрямів підтримки належить: диверсифікація сільської економіки, поліпшення якості людського життя, соціально-орієнтована підтримка різних верств населення, раціональне використання природних ресурсів, підтримка соціальних ініціатив сільських мешканців.

Саме комплексний розвиток сільських територій $є$ передумовою забезпечення якісного життя та добробуту сільського жителя. Аграрне виробництво повинно розглядатися як складова частина розвитку сучасного села.

Соціоінфраструктурне забезпечення сільських територій зумовлюється сукупністю об'єктів соціальної сфери, що надають послуги з обслуговування сільського населення, зокрема: житлове та комунальне господарство, транспорт і зв'язок, торгівля, громадське харчування, охорона здоров'я, освіта, культура, мистецтво та спорт.

Житлове та комунальне господарство $є$ основними елементами сільської соціальної інфраструктури, де здійснюється обслуговування житлового фонду населеного пункту, надання комунальних послуг, виконання робіт у житлових будинках та на прибудинкових територіях, проведення технічної політики з питань теплофікації, електропостачання, модернізації, оснащення їх інженерним устаткуванням.

Житловий фонд України, на початок 2018 р., становив 933,3 млн. м², 3 якого 39 \% - житловий фонд сільської місцевості (табл. 1).

Таблиця 1

Житловий фонд за 2010-2018 рр. ${ }^{3}$

\begin{tabular}{|l|c|c|c|c|c|c|c|c|}
\hline & 2010 & 2012 & 2013 & 2014 & 2015 & 2016 & 2017 & 2018 \\
\hline Житловий фонд & 1079,5 & 1094,2 & 1096,6 & 966,1 & 973,8 & 977,9 & 984,8 & 993,3 \\
\hline $\begin{array}{l}\text { Житловий фонд у сільській } \\
\text { місцевості }\end{array}$ & 386,5 & 393,5 & 396,5 & 378,0 & 381,3 & 383,9 & 385,4 & 387,8 \\
\hline
\end{tabular}

\footnotetext{
${ }^{1}$ Барановський, М. О. (2009). Наукові засади суспільно-географіного вивчення сільських депресивних територій України. Ніжин: Лисенко М. М.

${ }^{2}$ Рябоконь, В. П., Рарок, Л. А. (2016). Розвиток соціальної інфраструктури сільських територій. Економіка АПК, 4, 56-57.

3 Державна Служба Статистики України (2019). Статистичний щзорічник України за 2010-2018 pp.

$<$ https://ukrstat.org/uk/druk/publicat/Arhiv_u/01/Arch_zor_zb.htm> (2020, травень, 24).
} 
Порівняльний аналіз динаміки житлового фонду за період 2010-2018 pp., засвідчує його тенденцію до зменшення (на 86,2 млн.м²), а стосовно житлового фонду сільської місцевості, тут помітне незначне зростання - на 1,3 млн.м².

Наявність будинків та їх площа не дають вичерпної характеристики житлового фонду. Важливими тут $є$ якісні показники з облаштування житла комунальними зручностями. Вагоме значення при цьому відіграє комунальна послуга, спрямована на забезпечення комунальними зручностями об'єктів виробничого та соціально-культурного призначення. Наданням житловокомунальних послуг у селі можуть займатися сільськогосподарські чи спеціально створені для цього підприємства або приватні особи. Обладнання житлового фонду сільської місцевості наведено у табл. 2.

Таблиця 2

\section{Обладнання житлового фонду у сільській місцевості за період 2010-2018 pp.}

(відсотків)

\begin{tabular}{|l|c|c|c|c|c|c|c|c|}
\hline & 2010 & 2012 & 2013 & 2014 & 2015 & 2016 & 2017 & 2018 \\
\hline $\begin{array}{l}\text { Частка загальної житлової } \\
\text { площі, обладнаної: }\end{array}$ & & & & & & & & \\
\hline водопроводом & 27,1 & 30,3 & 31,5 & 33,4 & 34,3 & 35,4 & 36,6 & 37,4 \\
\hline каналізацією & 23,2 & 26,4 & 27,7 & 29,9 & 30,9 & 31,9 & 33,0 & 33,8 \\
\hline опаленням & 36,1 & 40,4 & 42,0 & 53,1 & 53,9 & 54,2 & 54,9 & 55,4 \\
\hline газом & 84,5 & 84,4 & 84,2 & 84,2 & 84,1 & 84,2 & 84,3 & 84,3 \\
\hline гарячим водопостачанням & 11,5 & 14,6 & 15,9 & 21,0 & 21,8 & 22,7 & 24,0 & 24,0 \\
\hline
\end{tabular}

За показниками табл. 2 частка житлової площі, обладнаної водопроводом, у сільській місцевості у 2018 р. становила $37,4 \%$, каналізацією - 33,8 \%, опаленням - 55,4 \%, газом - 84,3 \%, гарячим водопостачанням - 24,0\%. Аналіз змін зазначених вище показників, за період 2010-2018 рр., засвідчує тенденції до їх підвищення, крім показника щодо гарячого водопостачання, рівень якого знизився на $12,5 \%$. Незважаючи на те, що спостерігається повільне поліпшення благоустрою сільського житлового фонду, його рівень значно поступається міському.

Необхідними складовими соціоінфраструктури сільських територій є транспорт і зв'язок. Транспортна мережа представлена в Україні залізничним, автомобільним, повітряним та трубопровідним видами транспорту. У сільській місцевості головним засобом транспортного обслуговування є приміське автобусне сполучення (табл. 3).

Таблиця 3

\section{Динаміка перевезення пасажирів автобусами приміського сполучення за період 2010-2018 рр.}

\begin{tabular}{|l|c|c|c|c|c|c|c|}
\hline & 2010 & 2013 & 2014 & 2015 & 2016 & 2017 & 2018 \\
\hline $\begin{array}{l}\text { Приміське сполучення, } \\
\text { автобуси }\end{array}$ & 655 & 621 & 539 & 460 & 407 & 392 & 349 \\
\hline
\end{tabular}

Кількість перевезених пасажирів у 2018 р. становила 349 млн. осіб, що порівняно з 2010 р. майже на половину менше (655 млн. осіб). Динаміка перевезення пасажирів автобусами приміського сполучення засвідчує тенденцію до зменшення кількості таких перевезень. Це може бути зумовлено погіршенням стану доріг та зменшенням кількості громадських транспортних засобів у сільських населених пунктах. Недостатність державного фінансування для будівництва та реконструкції автомобільних доріг гальмує розвиток дорожньої інфраструктури сільських територій, створює окремі незручності для сільських жителів щодо транспортного обслуговування.

\footnotetext{
1 Державна Служба Статистики України (2019). Статистичний щзорічник України за 2010-2018 рр. $<$ https://ukrstat.org/uk/druk/publicat/Arhiv_u/01/Arch_zor_zb.htm> (2020, травень, 24).
} 
Однією 3 найважливіших галузей соціальної інфраструктури є зв'язок, який задовольняє потреби споживачів, органів державної влади, місцевого самоврядування, оборони і безпеки держави у засобах i різноманітних послугах зв'язку. ${ }^{1}$ Зв'язок $\epsilon$ необхідним елементом комунікації та інформування населення, а також допоміжним засобом у сфері торгівлі, освіти, культури та інших галузях. В Україні діє розвинена система зв'язку, міжнародна система телефонної комунікації, комп'ютерного, мобільного зв'язку, світова мережа Інтернет. Згідно із статистичними даними станом на 2018 р. обсяг реалізованих послуг населенню у сфері телекомунікацій та поштового зв'язку в містах та селах України становив 2066 млн. грн. Серед вище згаданих послуг зв'язку - міжміські (включаючи міжнародні), кур'єрська діяльність, проводове мовлення та інші. ${ }^{2}$ У сільській місцевості досить потужно розвивається комп'ютерний та мобільний зв'язок, доступною є мережа Інтернет.

Важливою складовою соціальної інфраструктури є сфера торгівлі і громадського харчування, що охоплює підприємства роздрібної торгівлі й ресторанного господарства. У загальному обсязі роздрібного товарообороту підприємств у 2018 р. продовольчі товари становили 43,3 \%, непродовольчі - 56,7 \%, у 2010 р. - продовольчі товари - $39 \%$, непродовольчі - $61 \%$. Сума роздрібного товарообороту підприємств у 2018 р. становила 668,4 млрд. грн, а у 2010 - 280,9 млрд. грн. ${ }^{3}$ Таким чином, простежується тенденція розширеного відтворення роздрібного товарообороту.

У торговій мережі сільських територій за спеціалізацією переважають продовольчі магазини, магазини та заклади швидкого харчування, які належать приватним підприємцям. Основну мережу ресторанного господарства у селі становлять кафе, бари, буфети.

Необхідна умова торгівлі на селі- забезпечення сільського населення продовольчими товарами, товарами народного споживання, культурно-побутового призначення і господарського вжитку. Для розширення торгової мережі у сільській місцевості варто реалізовувати програми стимулювання розвитку малого та сімейного бізнесу.

Важливу роль для інтелектуального розвитку суспільства, духовного та фізичного збагачення, формування індивіду як особистості відіграє освіта. Потреба в освіті $є$ однією з найперших суспільних потреб, оскільки вона становить основу духовного, соціального, економічного розвитку суспільства і держави. Функціональне призначення освіти як ланки соціальної інфраструктури полягає у нагромадженні знань, створенні умов для їх засвоєння кожним членом суспільства. ${ }^{4}$ Серед важливих показників забезпеченості населення освітніми послугами є наявність об'єктів освіти в межах сільських територій. При цьому, освітні заклади $є$ закладами, які надають освітні послуги суспільству, зокрема заклади дошкільної освіти (дитячі ясла і садки), заклади загальної середньої освіти (школи), заклади професійної та вищої освіти (університети, інститути та ПТУ).

Дошкільні заклади освіти - первинна ланка освіти. Їх кількість, кількість місць та дітей у закладах наведено у табл. 4.

Таблиця 4

Дошкільні навчальні заклади за період 2010-2018 рр.

\begin{tabular}{|l|c|c|c|c|c|c|c|c|}
\hline & 2010 & 2012 & 2013 & 2014 & 2015 & 2016 & 2017 & 2018 \\
\hline Кількість закладів, тис & 15,6 & 16,4 & 16,7 & 15,0 & 14,8 & 14,9 & 14,9 & 14,9 \\
\hline у сільській місцевості & 8,9 & 9,5 & 9,8 & 9,3 & 9,1 & 9,2 & 9,1 & 9,1 \\
\hline У них місць, тис. & 1136 & 1204 & 1236 & 1077 & 1105 & 1125 & 1141 & 1156 \\
\hline у сільській місцевості & 315 & 340 & 356 & 329 & 333 & 340 & 347 & 350 \\
\hline $\begin{array}{l}\text { Кількість дітей у закладах, } \\
\text { тис. осіб }\end{array}$ & 1273 & 1428 & 1471 & 1295 & 1291 & 1300 & 1304 & 1278 \\
\hline у сільській місцевості & 261 & 313 & 326 & 310 & 310 & 316 & 319 & 309 \\
\hline
\end{tabular}

\footnotetext{
${ }^{1}$ Саблук, П. Т., Орлатий, М. К. (2002). Соиіальна інфраструктура села. Київ: Ін-т аграрної економіки УААН, 336.

2 Державна Служба Статистики України (2019). Статистичний щорічник Украӥни за 2010-2018 pp.

$<\mathrm{https}: / /$ ukrstat.org/uk/druk/publicat/Arhiv_u/01/Arch_zor_zb.htm> (2020, травень, 24).

3 Державна Служба Статистики України (2020). Внутрішня торгівля.

$<$ http://www.ukrstat.gov.ua/druk/publicat/kat_u/publtorg_u.htm> (2020, травень, 28).

${ }^{4}$ Саблук, П. Т., Орлатий, М. К. (2002). Соиіальна інфраструктура села. Київ: Ін-т аграрної економіки УААН, 185.
} 
Станом на 2018 рік в Україні нараховувалося 14,9 тис. дошкільних навчальних закладів, серед них у сільській місцевості - 9,1 тис. У них місць у загальному - 1156 тис., а у сільській місцевості 350 тис. Кількість дітей, які виховуються в закладах - 1278 тис, у сільській місцевості - 309 тис. Якщо проаналізувати зазначені показники з попередніми роками, то порівняно з 2010 р. загальна кількість закладів скоротилася на 0,7 тис., у сільській місцевості - на 0,2 тис. збільшилася. Кількість місць збільшилася на 20 тис., а в сільській місцевості - на 35 тис. Водночас кількість дітей у дошкільних закладах також зросла відповідно на 5 тис. та 48 тис. осіб.

Заклади загальної середньої освіти є основною складовою серед елементів освіти (табл. 5). Показники табл. 5 свідчать, що за період 2010-2018 рр. кількість закладів освіти зменшилася на 4,3 тис., а у сільській місцевості - на 2,3 тис.

Таблиця 5

Заклади загальної середньої освіти за період 2010-2018 pp.

\begin{tabular}{|l|c|c|c|c|c|}
\hline \multicolumn{1}{|c|}{ Показники } & $2010 / 11$ & $2014 / 15$ & $2015 / 16$ & $2016 / 17$ & $2017 / 18$ \\
\hline Кількість закладів, тис. & 20,3 & 17,6 & 17,3 & 16,9 & 16,2 \\
\hline у сільській місцевості & 12,9 & 11,9 & 11,7 & 11,2 & 10,6 \\
\hline
\end{tabular}

Таким чином, спостерігається тенденція до скорочення кількості шкіл у сільській місцевості. Значна частина закладів освіти вимагає капітального ремонту, що потребує відповідного фінансування. Ці питання органи державної влади вирішують двома шляхами: виділенням коштів на відновлення та ремонт вищезгаданих об'єктів, або закриттям малоперспективних сільських шкіл та організацією довозу учнів для навчання в сусідніх закладах освіти.

Заклади вищої освіти здебільшого функціонують у містах чи районних центрах регіонів. Сільська молодь по закінченню закладів загальної середньої освіти обирає ВУЗ, до якого прагне вступити, та майбутню професію, яка їй більше до вподоби.

Галузь освіти тісно пов'язана з розвитком культури і мистецтва у сільській місцевості. При цьому, культура $є$ сферою діяльності, яка забезпечує задоволення духовних потреб населення, формує здібності та естетичні смаки, створює умови для творчого розвитку.

Кількість закладів культури за період 2010-2018 рр. (табл. 6) помітно зменшується, таке зменшення простежується і у сільській місцевості, аналогічна ситуація й щодо кількості бібліотек. Станом на 2018 рік в Україні нараховувалося 17017 клубів, з них у сільській місцевості - 15431, кількість бібліотек - 16601, у селах - 13311. Значна частка закладів культури через дефіцит коштів закривається, наявна матеріальна база культурних установ не відповідає вимогам, а низький рівень платоспроможності населення зумовлює втрату інтересу до існуючих форм проведення дозвілля i відпочинку.

Таблиця 6

Кількість закладів культури та бібліотек за період 2010-2018 рр.

\begin{tabular}{|l|c|c|c|c|c|c|c|c|}
\hline & 2010 & 2012 & 2013 & 2014 & 2015 & 2016 & 2017 & 2018 \\
\hline $\begin{array}{l}\text { Кількість закладів культури } \\
\text { (клуби) }\end{array}$ & 18593 & 18476 & 18452 & 16823 & 17195 & 17133 & 17090 & 17017 \\
\hline $\begin{array}{l}\text { у сільській місцевості } \\
\text { (клуби) }\end{array}$ & 16471 & 16396 & 16395 & 15302 & 15591 & 15534 & 15491 & 15431 \\
\hline Кількість бібліотек & 19487 & 19216 & 19135 & 16889 & 17272 & 17003 & 16824 & 16601 \\
\hline у сільській місцевості & 14870 & 14673 & 14631 & 13532 & 13710 & 13524 & 13393 & 13311 \\
\hline
\end{tabular}

Запорукою зміцнення здоров'я, покращення рівня працездатності людини є заняття спортом та фізичною культурою. Можливості оздоровлення сільського населення через спорт та фізкультуру досить обмежені, оскільки функціонуюча мережа спортивних споруд перебуває в аварійному стані, а спортивні майданчики необладнані належним чином. У сільській місцевості України функції спортивно-масової роботи виконує фізкультурно-спортивне товариство «Колос», яке здійснює організацію та проведення фізкультурно-спортивних заходів на селі. Через низький рівень матеріально-технічної бази, ефективно здійснювати цю роботи неможливо. Водночас, недостатньої 
уваги розвитку фізичної культури і спорту на селі приділяють громадські організації фізкультурноспортивної спрямованості.

Медичне обслуговування на селі має особливу специфіку. Це ціла система взаємопов'язаних закладів охорони здоров'я, що об'єднує обласні, центральні районні, районні, дільничні лікарні, диспансери, спеціалізовані лікарні. Мережа лікувально-профілактичних закладів, розташованих у сільській місцевості, має негативну тенденцію до зменшення за період 2010-2017 рр. (табл. 7). Так, кількість лікарняних закладів за аналізований період скоротилася з 543 до 52, що водночас спричинило зменшення кількості ліжок з 12277 до 2734. Також зменшилася кількість районних лікарень на 15 од., дільничних лікарень на 471 од., кількість самостійних лікарських амбулаторій та поліклінік - на 2966 од., кількість фельдшерсько-акушерських пунктів - на 1929 од., диспансери та спеціалізовані лікарні взагалі закрили.

Таблиця 7

\section{Мережа лікувально-профілактичних закладів, розташованих у сільській місцевості ${ }^{1}$}

(заклади, що перебувають у сфері управління Міністерства охорони здоров’я України)

(на кінець року, од.)

\begin{tabular}{|l|c|c|c|c|c|c|c|}
\hline & 2010 & 2012 & 2013 & 2014 & 2015 & 2016 & 2017 \\
\hline Кількість лікарняних закладів & 543 & 268 & 114 & 104 & 74 & 63 & 52 \\
\hline у них ліжок & 12277 & 6486 & 3832 & 3385 & 3128 & 2768 & 2734 \\
\hline $\begin{array}{l}\text { Iз загальної кількості } \\
\text { лікарняних закладів }\end{array}$ & & & & & & & \\
\hline центральні районні лікарні & 6 & 8 & 8 & 28 & 9 & 9 & 10 \\
\hline районні лікарні & 28 & 19 & 16 & 14 & 14 & 14 & 13 \\
\hline дільничні лікарні & 497 & 238 & 88 & 60 & 49 & 37 & 26 \\
\hline диспансери & 3 & 2 & 1 & 1 & 1 & 1 & - \\
\hline спеціалізовані лікарні & 8 & 1 & - & - & - & - & - \\
\hline інші заклади & 1 & - & 1 & 1 & 1 & 2 & 3 \\
\hline $\begin{array}{l}\text { Кількість самостійних } \\
\text { лікарських амбулаторій та } \\
\text { поліклінік }\end{array}$ & 3440 & 2988 & 911 & 591 & 525 & 468 & 474 \\
\hline $\begin{array}{l}\text { Кількість фельдшерсько- } \\
\text { акушерських пунктів }\end{array}$ & 14934 & 11553 & 14154 & 13295 & 13205 & 13133 & 13005 \\
\hline
\end{tabular}

Таким чином, у сільській місцевості відсутня належна мережа медичних закладів, вона характеризується територіальною віддаленістю від сільських мешканців, за рахунок цього практично відсутня служба швидкої допомоги на селі. Незадовільне надання медичних послуг, застаріле медичне устаткування, нерозвинена мережа аптек, брак медичного персоналу призводять до підвищення захворюваності та рівня смертності сільського населення.

До найгостріших проблем розвитку соціоінфраструктури сільських населених пунктів України, варто віднести: неналежне державне фінансування об'єктів соціальної інфраструктури для їх ефективного функціонування та розвитку; відсутність дієвих стимулів залучення коштів з інших джерел; недосконала система територіального розміщення об'єктів соціальної інфраструктури; незадовільні умови й низька мотивація праці для працівників соціальної сфери в сільській місцевості; низька якість послуг, що надаються населенню об’єктами соціальної інфраструктури та інші.

Основними напрямами вирішення питань соціоінфраструктурного забезпечення сільських територій повинні стати:

- удосконалення системи управління соціальною сферою в сільській місцевості;

- нормативно-правове та фінансово-економічне забезпечення;

- моніторинг та контроль відновлення об'єктів соціальної інфраструктури;

\footnotetext{
${ }^{1}$ Державна Служба Статистики України (2020). Охорона здоров'я.

$<$ http://www.ukrstat.gov.ua/druk/publicat/Arhiv_u/15/Arch_zozd_bl.htm> (2020, травень, 28).
} 
- забезпечення доступності, у сфері охорони здоров'я, обсягу медичних послуг і лікарських засобів, оскільки мова йде про найцінніше - життя і здоров'я людини, зокрема сільських мешканців.

Напрями розвитку соціальної інфраструктури повинні бути системою взаємозв'язаних заходів, спрямованих на вирішення конкретних завдань та досягнення цілей у задоволенні життєвих потреб сільських мешканців.

Необхідним є розроблення соціальної програми розвитку і розміщення сільської соціальної інфраструктури та належна фінансова підтримка, спрямована на поліпшення умов праці й життя сільського населення. Важливого значення набуває взаємоузгодженість міжбюджетних відносин, збалансоване поєднання виділення фінансових ресурсів із державного бюджету та коштів із місцевих бюджетів для розвитку соціоінфраструктури на селі.

Висновки. Розвиток сільських територій значно залежить від соціоінфраструктурного забезпечення. Комплексна оцінка розвитку сільської місцевості дає можливість проаналізувати систему державного управління розвитком сільських територій; визначити систему цілей, головну мету і проміжні результати; врахувати причинно-наслідкову залежність, виявити особливості управлінського впливу на функціонування та ефективність розвитку українського села. При цьому, соціальна інфраструктура $\epsilon$ складною системою, яка створює необхідні передумови для життедіяльності та відтворення робочої сили, підвищення рівня освіти, культури та охорони здоров'я, обслуговування житлового фонду, забезпечення населення продовольчими та непродовольчими товарами через мережу торгових установ, надання транспортних та комунікаційних послуг, тобто задоволення потреб сільського населення. Оцінювання об'єктів соціальної інфраструктури сільських територій дало можливість окреслити основні проблеми та тенденції соціоінфраструктурного забезпечення сільських територій.

Подальших досліджень потребує виокремлення інноваційних шляхів і підходів до соціоінфраструктурного забезпечення сільських територій та вивчення міжнародного досвіду щодо покращення рівня життя сільських мешканців.

\section{References:}

1. Baranovskyi, M. O. (2009). Naukovi zasady suspilno-heohrafinoho vyvchennia silskykh depresyvnykh terytorii Ukrainy [Scientific bases of socio-geographical study of rural depressed territories of Ukraine: monograph]. Nizhyn: Lysenko M. M. [in Ukrainian].

2. Borodina, O. (2009). Silskyj rozvytok v Ukrajini: problemy [Rural development in Ukraine: problems]. Ekonomika Ukrayiny [Economy of Ukraine], 5, 59-67. [in Ukrainian].

3. Hazuda, L. M., Erfan, V. J., Hazuda, S. M. (2015). Silskyj rozvytok rehionu [Rural development of the region]. Uzhhorod. [in Ukrainian].

4. State Statistics Service of Ukraine (2020). Osvita [Education]. $<$ http://www.ukrstat.gov.ua/druk/publicat/kat_u/publosvita_u.htm>. (2020, May, 25). [in Ukrainian].

5. State Statistics Service of Ukraine (2020). Okhorona zdorovja [Health care] $<$ http://www.ukrstat.gov.ua/druk/publicat/Arhiv_u/15/Arch_zozd_bl.htm>. (2020, May, 28). [in Ukrainian].

6. Rjabokon, V. P., Rarok, L. A. (2016). Rozvytok socialnoji infrastruktury silskykh terytorij [Development of social infrastructure of rural areas]. Ekonomika APK [Economics of agro-industrial complex], 4, 56-65. [in Ukrainian].

7. Sabluk, P. T. (2006). Rozvytok silskykh terytorij - zaporuka vidrodzhennja ahrarnoji Ukrajiny [Rural development is the key to the revival of agrarian Ukraine]. Visnyk ahrarnykh nauk [Bulletin of Agrarian Sciences], 5, 24-23. [in Ukrainian].

8. Sabluk, P. T., Orlatyj, M. K. (2002). Socialna infrastruktura sela [Social infrastructure of the village]. Kyiv: Inst. Of Agrarian Economics UAAS. [in Ukrainian].

9. State Statistics Service of Ukraine (2019). Statystychnyy shchorichnyk Ukrayiny za 2010-2018 rr [Statistical Yearbook of Ukraine for 2010-2018] <https://ukrstat.org/uk/druk/publicat/Arhiv_u/01/Arch_zor_zb.htm>. (2020, May, 24). [in Ukrainian].

10. Tkachuk, V. A. (2013). Rozvytok socialnoji infrastruktury silskykh terytorij Ukrajiny v konteksti jikh staloho rozvytku [Development of social infrastructure of rural areas of Ukraine in the context of their sustainable development]. Visnyk ahrarnykh nauk chornomorskoho rehionu [Bulletin of Agrarian Science of the Black Sea Region], 3, 69-80. [in Ukrainian].

11. State Statistics Service of Ukraine (2020). Vnutrishnja torhivlja [Domestic trade]. $<$ http://www.ukrstat.gov.ua/druk/publicat/kat_u/publtorg_u.htm>. (2020, May, 25). [in Ukrainian].

12. State Statistics Service of Ukraine (2018). Zakklady okhorony zdorovja [Health care facilities]. Available at: http://www.ukrstat.gov.ua/druk/publicat/kat_u/2018/zb/06/zb_zoz_17.pdf>. (2020, May, 25). [in Ukrainian]. 